\title{
Excruciating Pain Within Pain: Significance of Disaster Management in K.V. Dominic's Poems
}

\author{
K. Ramya Kalaivani and Raichel M. Sylus \\ Department of English, Avinashilingam Institute for Home \\ Science and Higher Education for Women, Coimbatore, India
}

\section{ABSTRACT}

Disaster management is a multi-layered process that manages the situation of emergencies and implement necessary changes to lessen the impact of disasters. Natural disasters bring severe damage to the environment and to the human society. The victims of disasters undergo mental trauma in its aftermath. According to appraisal theory of emotion, the emotional outburst of a person is a result of their perception to an event. A change in their perception is required to build resilience within them. In order to change their interpretation, there are some changes to be implemented. Besides the sufferings of people, environment is also badly affected. There are various man-made activities which are harmful to the environment in the relief camps. In the poems "Tsunami Camps" and "Tearful Exodus", K.V. Dominic picturises the trauma of people who are facing the disaster. This paper entitled "Scrutinising the Significance of Disaster Management in K.V. Dominic's Poems" examines the importance of handling the mental pressure at the time of disaster. This paper also voices out the activities which are against the environment in the relief camps.

\section{KEY WORDS: APPRAISAL, DISASTER, EMOTION, ENVIRONMENT, RESILIENCE}

\section{INTRODUCTION}

Every region in the world has unique geo-climatic condition and are vulnerable to various natural disasters such as floods, droughts, tsunami, volcano, earthquakes, cyclones, hurricanes, landslides and so on. Natural disasters are naturally occurring physical phenomena that either make slight damages or severe destruction to the places it attacks. They destroy the natural resources which are vital to the livelihood of people. In the aftermath of the disasters, not only human beings are suffered, but also the environment is affected. Hence, disaster management plays a key role in fixing up the damages.

Imprint of Disaster in Dominic's Poems: Many writers have addressed the impact of disasters in their works. One such writer is K.V. Dominic. He is an Indian poet, short story writer, editor and a critic. He covers wide range of themes such as deforestation, climate change,

Biosc Biotech Res Comm P-ISSN: 0974-6455 E-ISSN: 2321-4007

\section{rossef}

Identifiers and Pagination

Year: 2021 Vol: 14 No (8) Special Issue

Pages: 66-68

This is an open access article under Creative

Commons License Attribn 4.0 Intl (CC-BY).

DOI: $h t t p: / / d x . d o i . o r g / 10.21786 / b b r c / 14.8 .16$ racism, multiculturalism, women's rights and so on. He also picturises the exact scenario during natural disasters where thousands of people are affected. Natural disasters not only destroy the physical property but also affect the mental stability of the people. The poem "Tsunami Camps" portrays the sufferings of the people in camps during tsunami. In "Tearful Exodus", the poet explains the migration of people as a result of drought. In both the scenario, people undergo emotional distress at the time of disaster and so building resilience becomes essential.

Appraisal Theory to Analyse Emotions: The appraisal theory of emotion has been developed by Magda Arnold and Richard Lazarus. According to this theory, the arousal of a person's emotion depends on their 'appraisals' of events. That is, a person's emotion is a result of their perception and interpretation to an event. Lazarus specifies two types of appraisal methods such as primary appraisal and secondary appraisal. Primary appraisal seeks to establish meaning to an event and the secondary appraisal assesses the ability of an individual to cope up with the consequences of an event. Through this theory, the emotions of the people who suffer during disasters can be analysed.

\section{Sufferings of Disaster Victims}

In "Tsunami Camps", Dominic discusses the dreadful life of people who are in tsunami camps. He states that they 
do not get sufficient food and water. They face imbalance in their livelihood. Many of them have lost their dear ones and have faced irreplaceable losses. They are in a state where their mind and body are filled with agony. Their state of depression is vivid in the lines, "Nothing left but mind and body; / counting days for their salvation ... It's better to kill us than torture like this" (Winged 33). The atmosphere in the camp is also not healthy. The poet mentions:

Each family has a cell in the camp;

They cook and dine and sleep at night;

Grown-ups sleep outside, risking nightly rains. .

"The filthy atmosphere of the camp

Will bring several epidemics." (Winged 33,34)

Disaster victims in relief camps undergo a lot of mental pressure. In tsunami camps, the potential threat for the victims is the word 'tsunami'. Tsunami is picturised as a big threat and so there is no possibility for the positive approach in primary appraisal. As a result, there is a development of negative consequences in their mind. The threat in disaster victims triggers the secondary appraisal. If there are effective options available to cope up the situation, the stress will be reduced. Hence, if the disaster victims are treated with proper care by providing shelter, food and maintaining good atmosphere in relief camps, their intensity of stress may be reduced. In addition to it, steps must be taken to bring back their livelihood as soon as possible.

The opening line of "Tearful Exodus" reveals that the poem is based on a real incident. A tribal village of Telangana has been badly hit by drought. The land has no traces of water and it is barren. Hundreds of people have been migrated leaving their houses, lands and livestock as they could not bear the immense heat. The poet explains a photograph in a newspaper where a mother is holding her three-year-old son. She gives her son to her relatives and has to go with her husband and two daughters to Mumbai. They are in search of a job for their survival. The poet mentions that they have become the victims of "nature's annihilating human villains" who have turned "fertile lands to arid wastelands" (Contemporary 42).

According to World Health Organisation, 55 million people are globally affected by drought every year. Also, 700 million people are at the risk of being displaced by 2030. Drought occurs when the amount of rainfall decreases and region becomes abnormally dry. One of the reasons for such climatic change is man-made activities. Dominic argues that the conversion of fertile lands to buildings has created a big impact in the environment and in society. He states:

and then lead luxurious lives in $\mathrm{AC}$ rooms and bathe in swimming pools in metro cities When miserable farmers in thousands make tearful exodus for their survival (Contemporary 42)

The potential threat for people who face drought is their inability to sustain in the changing environment. They suffer from depression and anxiety about their loss of livelihood. People has to relocate their places and the possibility of positive approach in primary appraisal is very minimal. Their sufferings trigger the secondary appraisal. They become a prey for someone's harmful activities against the environment. As they relocate to a different place, it takes more time to adapt with the new environment. If the victims build resilience, they will face less threat. If not, droughts can lead to impaired mental health and stress. On the other hand, if the conditions such as pollution, deforestation and global warming are reduced, there will be a healthier environment. In order to prevent the mental trauma in disaster victims, it is essential to build resilience and approach the catastrophe in a positive manner.

Disaster's Impact on Environment: Natural disaster not only makes disastrous effect among humans but also worsen the environment. Disasters destroy the natural resources of sea and land. Besides the effect of nature, human activities also make a negative impact in the environment. In the aftermath of disaster, there is a possibility of increase in pollution level. Food packets, water bottles and several essential items are distributed in relief camps. "Rushed 2 lakh litres of water bottles for flood affected people of Jammu \& Kashmir as advised by the Prime Minister" - a report in India Today. This clearly indicates that huge number of water bottles are used at the time of disasters. It is estimated that "a single water bottle can take up to 1000 years to break down" (3). Hence, it is essential to minimise the usage of plastic water bottle. Recyclable bottles, paper water bottle, aluminium bottles and so on can be given as an alternative to the plastic water bottles in relief camps. Even though they are not cost efficient, they reduce more wastage.

During heavy rainfall, styrofoam sheets are used as waterproofing material in some relief camps. "Volunteers were busy 'waterproofing' the cloth walls of the tents by placing styrofoam sheets against them" - a report in Times of India. The Earth Resource Foundation reports that Styrofoam manufacturers were the fifth largest producer of toxic waste in 1986. It is one of the most environmental unfriendly types of waste as it is non-biodegradable and it takes thousands of years to decompose. As it is harmful to the environment, an eco-friendly alternative to styrofoam material must be used.

Alternative Measures in Relief Camps: Natural disasters make huge impact among human beings and in the environment. Hence, if the disaster management is followed in a proper manner, several negative consequences will be controlled. Emotional support is much needed for the disaster victims to build resilience within them. This aids them in developing a positive approach in the aftermath of disasters. By replacing ecofriendly products for the usual kit in relief camps, a vast number of non-biodegradable waste can be minimised. 
This helps in protecting the environment from further damage after being hit by a disaster.

\section{CONCLUSION}

Disasters are unpredictable and so the implementation of such preventive measures can help to reduce the havoc in a disaster area. Every individual has the responsibility to protect the environment and must take initiatives in implementing the necessary changes. Robert Swan rightly says, "The greatest threat to our planet is the belief that someone else will save it".

\section{REFERECES}

Ajmal, Anam. "Heavy rain further dampens spirits at relief camp.” Times of India, 7 Mar. 2020. m.timesofindia. com/city/delhi/heavy-rain-further-dampens-spiritis-atrelief-camp/amp_articleshow/74522048.cms
Dominic, K.V. Contemporary Concerns and Beyond. Authors Press, 2016, p. 42.

Dominic, K.V. Winged Reason. Authors Press, 2010, pp. 33, 34.

"Drought." World Health Organization. Accessed on 17 Dec. 2020. www.who.int/health-topics/drought

"LIVE updates on Jammu and Kashmir floods: Over 1,10,000 people rescued so far, many still await help." India Today, 12 Sep. 2014. www.indiatoday.in/india/ story/live-jammu-and-kashmir-floods-kashmir-floodsrescue-operations-291887-2014-09-11

"Plastic Waste: A Global Concern." Plastic Waste Management: Issues, Solutions \& Case Studies, Ministry of Housing and Urban Affairs, Government of India, 2019, p.3.

Swan, Robert. "Robert Swan - Stories from Beyond Poles.” Ecologic, 2014. www.ecologic.eu/11745 